\title{
NITROGEN METABOLISM IN ACUTE INFECTIONS ${ }^{1}$
}

\author{
By CHARLES M. GROSSMAN, THOMAS S. SAPPINGTON, BELTON A. BURROWS, \\ PAUL H. LAVIETES, AND JOHN P. PETERS
}

(From the Department of Internal Medicine, Yale University School of Medicine, New Haven)

(Received for publication November 13, 1944)

Wastage of nitrogen in severe infectious diseases has long been recognized. More recently, it has been discovered that surgical operations and trauma induce the same process. Much evidence has accumulated that, in the acute stages of all these conditions, the losses of nitrogen can be prevented or mitigated with difficulty, if at all, by the administration of unusually large quantities of protein or high calories, or both. The subject has been recently reviewed by one of the authors (1).

On a priori grounds, losses of nitrogen, which must be derived from proteins of the tissues, would seem to be undesirable. It has been generally assumed that the body has no surplus stores of protein and, consequently, that losses sustained through disease, injury, or deprivation must be replaced before a subject is restored to full health and strength. If this is true, it becomes a matter of no small importance to find a means to prevent these losses and thus to hasten convalescence and rehabilitation.

Studies of the subject have been confined chiefly to major diseases and injuries. Obviously, however, from the standpoint of conservation of manpower, the ordinary run of the mill illnesses and injuries are of the greatest importance, because it is the victims of these that may be returned most rapidly to normal life. The present study is aimed to measure the nitrogen excretion in such common conditions and to ascertain how far nitrogen wastage may be prevented by dietetic measures. Since it is obviously unpractical to use parenteral or other abnormal methods of feeding for all patients in the hospital, such methods have been practised in this study for only one purpose: to learn whether the administration of supplementary protein to the diet of a patient would pre-

\footnotetext{
1 The work described in this paper was done under a contract, recommended by the Committee on Medical Research, between the Office of Scientific Research and Development and the Yale University School of Medicine.
}

vent nitrogen losses that could not be prevented by dietary measures alone.

\section{EXPERIMENTAL PROCEDURE}

Patients on the wards of the New Haven Hospital were used, young adult males being selected, as far as possible. One female patient, JK, was included. Studies were terminated as soon as patients came into positive nitrogen balance or when they were discharged from the hospital.

Chemical procedures. - Urine, feces, vomitus, and in one case sputum, were analyzed for total nitrogen by the macro-Kjeldahl technique. Twenty-four-hour urine specimens, preserved with benzoic acid, were analyzed daily. Stools, collected in Pyrex glass beanpots, were quantitatively transferred to jars containing benzoic acid. The combined stools were analyzed at convenient intervals. The quantity of nitrogen in each specimen was divided by the number of days over which it had been collected and the average thus obtained was used for calculation of the daily nitrogen balances in that period. The total fecal mass, diluted with water to a convenient weight and consistency, was thoroughly mixed with a motor-driven mechanical stirrer for at least 20 minutes. Aliquots, obtained while the stirrer was running, were transferred to weighed Kjeldahl flasks, which were then reweighed. Vomitus and sputum were analyzed separately by similar procedures.

Blood was collected before breakfast at the beginning and end of each experiment. The non-protein nitrogen of whole oxalated blood was measured by the micro-Kjeldahl technique. Total protein and protein fractions were measured in serum from blood drawn and centrifuged with anaerobic precautions. Cell volume was measured by hematocrit on blood defibrinated anaerobically with mercury. All analyses were made in duplicate and were repeated when duplicates did not check.

Diets. Liquid, soft, or regular diets were used, according to the condition of the patients. The basic liquid diet was prepared to contain 100 grams of protein and 3000 Calories. A mixture made by adding 10 grams of skimmed milk powder to $100 \mathrm{ml}$. of milk and flavoring with a few drops of vanilla was found useful. Each liter of this mixture contained 67 grams of protein and provided 900 Calories. When well mixed, it was quite palatable, tasting like an ordinary milkshake. The basic soft and regular diets were prepared to contain 125 grams of protein and 3500 Calories. Uneaten portions of each meal were weighed and the amounts deducted from the diets offered.

The nitrogen in the diets was calculated by means of 
the usual dietary charts. These calculations were, however, checked by weekly analyses of duplicate diets by the macro-Kjeldahl technique. The diet, ground up by a meat grinder was suspended in water and treated in the manner described for the analysis of stools above.

The liquid diets, instead of the calculated 16 grams of $\mathrm{N}$, were found, on 6 analyses, to contain 12.6 to 15.9 grams; the solid diets, instead of 20 grams, contained, on 15 analyses, from 16.5 to 22.6 grams of $\mathrm{N}$.

General care. Special nurses were in attendance upon the patients throughout. This not only insured accuracy in the administration of food and the collection of specimens; it also contributed to success in feeding. Many of the patients would have taken far less food during the more severe stages of their illnesses, had it not been for the skillful services of these nurses.

Except for the administration of food and fluids and attention to general comfort that might be conducive to appetite, the care of the patients was left to the regular physicians and surgeons of the hospital staff. Supervision of the details of the project and liaison between the laboratory and wards were entrusted to a special physician who spent his full time on the project.

Amigen, a hydrolyzate of casein and pork pancreas, prepared by Mead Johnson and Co., ${ }^{1}$ was given intravenously to certain of the patients, in 5 per cent solution with 5 per cent glucose. Doses of $500 \mathrm{ml}$. were injected slowly over a period of 2 to 3 hours. It was assumed that such a dose contained 6 grams of $\mathrm{N}$.

Amigen was given only when patients took little or nothing by mouth, as supplements to the diets when the $\mathrm{N}$-intake was obviously inadequate, or when it was known that there was a large negative nitrogen balance. In the last case, Amigen was given on single days in order that the effect of a large addition of nitrogen upon the nitrogen balance might be evaluated.

\section{OBSERVATIONS}

Balance studies were conducted on 45 patients. The duration of studies on individual patients varied as follows: 7 patients were observed for only 2 to 3 days, because they were discharged at the end of this period, with 1 exception in positive nitrogen balance; 37 patients were observed from 4 to 22 days; one was observed 43 days.

There were 22 patients with medical conditions : 10 meningococcus meningitis (2 with complicating polyarthritis), 2 pneumococcus pneumonia, 2 scarlet fever, 3 upper respiratory infections, and 1 each of subacute bacterial endocarditis, lung abscess, peritonsillar abscess, acute rheumatic fever, and regional enteritis. Acute febrile illnesses were studied as they were admitted. Meningococ-

1 The Amigen used for this study was supplied by Mead Johnson and Co. cus meningitis happened to be the prevalent major infection at the time of the study.

The remaining 23 patients had surgical conditions: 9 appendectomies, 3 herniorrhaphies, 3 fractures of long bones, 2 skin infections, 2 chronic osteomyelitis, 1 saphenous vein ligation, 1 radical mastoidectomy, 1 traumatic rupture of the iliopsoas muscle with evacuation of an extraperitoneal hematoma, and 1 excision and curettage of a bone cyst.

Amigen was given to 4 of the patients with meningitis, 6 appendectomies, 2 fractures, 1 herniorrhaphy, and 1 regional enteritis. In the surgical patients, it was used when the patients could take little or nothing by mouth.

Table I summarizes the data from all cases. The first column indicates the day of the disease on which the study was begun. In the operative cases, the days are numbered from the day of operation, except in the case of LK, in which the study was begun 5 days after injury or 2 days after operation. The total duration of each study is the sum of the days in positive and in negative balance (PSe and AI were each studied one day longer than this, but in each case one day was omitted because urine collection was incomplete). In all cases except PSe, $\mathrm{KS}$, and JK, the days of positive nitrogen balance were at the end of the study, following a variable period of negative balance. In these 3 patients, days of positive and negative balance were interspersed. The temperature column shows the number of days on which at least one temperature reading was $100^{\circ} \mathrm{F}$. or more by rectum, or $99^{\circ}$ or over by mouth. In operative cases, a double set of nitrogen balance figures is given for those patients who took little or nothing during the period immediately after operation. The upper figures represent the nitrogen metabolism for this period, the lower figures, the nitrogen metabolism for the remainder of the period of negative balance.

Figures 1 and 2 show the complete nitrogen metabolism of 5 of the meningitis cases and 8 of the appendectomies. The nitrogen balances of 3 other appendectomy cases are shown below Figure 2. The nitrogen intakes of these 3 patients after the first few postoperative days were adequate and fairly uniform, averaging well over 14 grams daily. The cases presented in detail in 
TABLE I

\begin{tabular}{|c|c|c|c|c|c|c|c|c|c|c|c|c|c|}
\hline \multirow{3}{*}{ Case } & \multirow{3}{*}{$\begin{array}{c}\text { Initial } \\
\text { day } \\
\text { of } \\
\text { dis- } \\
\text { ease }\end{array}$} & \multicolumn{7}{|c|}{ Nitrogen } & \multirow{3}{*}{$\begin{array}{l}\text { Tem- } \\
\text { pera- } \\
\text { ture }\end{array}$} & \multirow{3}{*}{$\begin{array}{c}\text { Signs } \\
\text { and } \\
\text { symps. }\end{array}$} & \multicolumn{2}{|c|}{ Change of serum } & \multirow{3}{*}{ Diagnosis } \\
\hline & & \multirow[b]{2}{*}{$\begin{array}{c}\text { Total } \\
\text { balance }\end{array}$} & \multicolumn{3}{|c|}{ Lost } & \multicolumn{3}{|c|}{ Stored } & & & & & \\
\hline & & & Daily & $\begin{array}{c}\text { Num- } \\
\text { ber of } \\
\text { days }\end{array}$ & $\begin{array}{c}\text { Aver- } \\
\text { age } \\
\text { intake }\end{array}$ & Daily & $\begin{array}{l}\text { Num- } \\
\text { ber of } \\
\text { days }\end{array}$ & $\begin{array}{l}\text { Aver- } \\
\text { age } \\
\text { intake }\end{array}$ & & & $\min$ & ulin & \\
\hline & & grams & grams & & $\begin{array}{c}\text { grams } \\
\text { per } \\
\text { day }\end{array}$ & grams & & $\begin{array}{c}\text { grams } \\
\text { per } \\
\text { day }\end{array}$ & \multicolumn{2}{|c|}{ no. of days } & \multicolumn{2}{|c|}{ grams per cent } & \\
\hline $\begin{array}{l}\text { EB } \\
\text { AI } \\
\text { PSh } \\
\text { JF } \\
\text { PV } \\
\text { TF } \\
\text { FC } \\
\text { PSe } \\
\text { HP }\end{array}$ & $\begin{array}{l}4 \\
4 \\
\mathbf{5} \\
6 \\
5 \\
\mathbf{5} \\
\mathbf{9} \\
9 \\
\mathbf{4} \\
\mathbf{3}\end{array}$ & $\begin{array}{r}-40 \\
-29 \\
-10 \\
-66 \\
-123 \\
-31 \\
-38 \\
-3 \\
-180\end{array}$ & $\begin{array}{r}4.0 \\
7.3 \\
2.5 \\
2.5 \\
7.4 \\
11.2 \\
6.2 \\
5.5 \\
2.2 \\
8.2\end{array}$ & $\begin{array}{r}10 \\
4 \\
4 \\
9 \\
11 \\
5 \\
7 \\
5 \\
22\end{array}$ & $\begin{array}{l}14 \\
12 \\
16 \\
16 \\
14 \\
18 \\
16 \\
16 \\
14\end{array}$ & $\begin{array}{l}0 \\
0 \\
0 \\
0.9 \\
0 \\
0 \\
0.9 \\
2.1 \\
0\end{array}$ & $\begin{array}{l}0 \\
0 \\
0 \\
1 \\
0 \\
0 \\
1 \\
4 \\
0\end{array}$ & $\begin{array}{l}29 \\
22\end{array}$ & $\begin{array}{r}2 \\
1 \\
0 \\
6 \\
6 \\
3 \\
4 \\
4 \\
18\end{array}$ & $\begin{array}{r}2 \\
1 \\
0 \\
5 \\
7 \\
2 \\
4 \\
3 \\
18\end{array}$ & $\begin{array}{r}+0.6 \\
+0.3 \\
+0.2 \\
+1.2 \\
+0.5 \\
+0.2 \\
+0.3 \\
-0.3 \\
+0.5\end{array}$ & $\begin{array}{l}+0.3 \\
-0.2 \\
-0.2 \\
+0.2 \\
+0.9 \\
+0.1 \\
+0.6 \\
+0.7 \\
+1.4\end{array}$ & $\begin{array}{l}\text { Meningitis } \\
\text { Meningitis } \\
\text { Meningitis } \\
\text { Meningitis } \\
\text { Meningitis } \\
\text { Meningitis } \\
\text { Meningitis } \\
\text { Meningitis } \\
\text { Meningitis with poly- }\end{array}$ \\
\hline ND & 3 & -126 & 7.0 & 19 & 16 & 2.3 & 3 & 16 & 18 & 17 & +0.3 & +0.7 & Meningitis with poly- \\
\hline $\begin{array}{l}\text { WZ } \\
\text { PSm } \\
\text { RG } \\
\text { GN } \\
\text { TP } \\
\text { FS }\end{array}$ & $\begin{array}{r}8 \\
6 \\
2 \\
5 \\
56 \\
131\end{array}$ & $\begin{array}{l}-25 \\
+9 \\
-34 \\
-18 \\
+19 \\
+4\end{array}$ & $\begin{array}{l}3.3 \\
0 \\
3.8 \\
3.1 \\
0 \\
0\end{array}$ & $\begin{array}{r}8 \\
0 \\
10 \\
7 \\
0 \\
0\end{array}$ & $\begin{array}{r}15 \\
0 \\
17 \\
18\end{array}$ & $\begin{array}{l}1.6 \\
2.3 \\
0.9 \\
1.0 \\
2.3 \\
1.4\end{array}$ & $\begin{array}{l}1 \\
4 \\
4 \\
3 \\
8 \\
3\end{array}$ & $\begin{array}{l}18 \\
17 \\
18 \\
18 \\
14 \\
14\end{array}$ & $\begin{array}{l}2 \\
1 \\
4 \\
0 \\
3 \\
3\end{array}$ & $\begin{array}{l}2 \\
0 \\
2 \\
0 \\
8 \\
3\end{array}$ & $\begin{array}{l}+0.9 \\
+0.4 \\
+0.4 \\
+0.6 \\
-0.1\end{array}$ & $\begin{array}{l}+1.0 \\
+0.5 \\
+0.2 \\
+0.2 \\
+0.2\end{array}$ & $\begin{array}{l}\text { Pneumonia } \\
\text { Pneumonia } \\
\text { Scarlet fever } \\
\text { Scarlet fever } \\
\text { Lung abscess } \\
\text { Subacute bacterial endo- } \\
\text { carditis }\end{array}$ \\
\hline ES & 17 & +2 & 0 & $\mathbf{0}$ & & 0.8 & 3 & 19 & 3 & 3 & & & $\begin{array}{l}\text { Sepsis, following wound } \\
\text { infection }\end{array}$ \\
\hline $\begin{array}{l}\text { HD } \\
\text { KS } \\
\text { MH } \\
\text { GB }\end{array}$ & $\begin{array}{c}43 \\
43 \\
11 \\
2^{1}\end{array}$ & $\begin{array}{l}+34 \\
+17 \\
+7 \\
-24\end{array}$ & $\begin{array}{c}0 \\
-0.7 \\
0 \\
-6.0 \\
70\end{array}$ & $\begin{array}{l}0 \\
5 \\
0 \\
4\end{array}$ & 18 & $\begin{array}{l}4.8 \\
1.7 \\
2.2 \\
0\end{array}$ & $\begin{array}{r}7 \\
12 \\
3 \\
0\end{array}$ & $\begin{array}{l}17 \\
14 \\
17\end{array}$ & $\begin{array}{l}0 \\
1^{2} \\
1^{3} \\
3^{2}\end{array}$ & $\begin{array}{l}5 \\
4 \\
0 \\
4\end{array}$ & $\begin{array}{l}+0.8 \\
+0.3\end{array}$ & $\begin{array}{c}0 \\
+0.1\end{array}$ & $\begin{array}{l}\text { Osteomyelitis } \\
\text { Rheumatic fever } \\
\text { Saphenous vein ligation } \\
\text { Mastoidectomy }\end{array}$ \\
\hline AM & Op.1 & -1 & $\left.\begin{array}{r}7.8 \\
-0.6\end{array}\right\}$ & $\left.\begin{array}{l}1 \\
4\end{array}\right\}$ & $\left.\begin{array}{r}1 \\
14\end{array}\right\}$ & 1.2 & 8 & 17 & $6^{2}$ & 3 & $\mathbf{0}$ & -0.1 & Herniorrhaphy \\
\hline JD & $1^{1}$ & -20 & $\left.\begin{array}{r}-20.1 \\
-1.8\end{array}\right\}$ & $\left.\begin{array}{l}1 \\
5\end{array}\right\}$ & $\left.\begin{array}{r}0 \\
18\end{array}\right\}$ & 1.4 & 7 & 19 & $3^{2}$ & 1 & -0.1 & +0.4 & Herniorrhaphy \\
\hline WT & Op..$^{1}$ & +4 & -3.6 & 3 & 13 & 1.8 & 8 & 18 & $3^{3}$ & 2 & -0.3 & +0.3 & Herniorrhaphy \\
\hline JK & Op.1 & +10 & $\left.\begin{array}{l}-6.3 \\
-2.4\end{array}\right\}$ & $\left.\begin{array}{l}1 \\
5\end{array}\right\}$ & $\left.\begin{array}{r}3 \\
14\end{array}\right\}$ & 2.0 & 14 & 17 & $18^{3}$ & 14 & -1.1 & +0.7 & Cyst of femur operation \\
\hline LK & 5 & -111 & $\left.\begin{array}{r}-19.1 \\
-6.0\end{array}\right\}$ & $\left.\begin{array}{r}2 \\
18\end{array}\right\}$ & $\left.\begin{array}{r}3 \\
18\end{array}\right\}$ & $\mathbf{0}$ & 0 & & $11^{8}$ & 5 & -0.4 & +1.3 & Hematoma \\
\hline$\underset{\mathrm{JC}}{\mathrm{HM}}$ & $\begin{array}{l}3 \\
2\end{array}$ & $\begin{array}{l}-93 \\
-95\end{array}$ & $\begin{array}{r}6.2 \\
11.9\end{array}$ & $\begin{array}{r}15 \\
8\end{array}$ & $\begin{array}{l}18 \\
17\end{array}$ & $\begin{array}{l}\mathbf{0} \\
\mathbf{0}\end{array}$ & $\begin{array}{l}\mathbf{0} \\
\mathbf{0}\end{array}$ & & $\begin{array}{l}7^{3} \\
3^{2}\end{array}$ & $\begin{array}{r}15 \\
8\end{array}$ & $\begin{array}{c}0 \\
-0.4\end{array}$ & $\begin{array}{l}+1.1 \\
+0.6\end{array}$ & $\begin{array}{l}\text { Fracture of femur } \\
\text { Fracture of ribs, tibiae } \\
\text { and fibulae }\end{array}$ \\
\hline JG & 2 & +16 & 0 & 0 & & 5.4 & 3 & 20 & $2^{3}$ & 3 & & & Fracture of tibia \\
\hline ED & 1 & -25 & $\left.\begin{array}{r}12.9 \\
2.1\end{array}\right\}$ & $\left.\begin{array}{l}1 \\
6\end{array}\right\}$ & $\left.\begin{array}{r}1 \\
18\end{array}\right\}$ & $\mathbf{0}$ & 0 & & $1^{8}$ & 1 & +0.5 & +0.4 & $\begin{array}{l}\text { Appendectomy, acute } \\
\text { appendicitis }\end{array}$ \\
\hline RW & Op..$^{1}$ & -52 & $\begin{array}{r}10.3 \\
3.5\end{array}$ & $\left.\begin{array}{l}3 \\
6\end{array}\right\}$ & $\left.\begin{array}{r}1 \\
16\end{array}\right\}$ & 1.6 & 1 & 16 & $5^{3}$ & 5 & 0 & +0.3 & $\begin{array}{l}\text { Appendectomy, acute } \\
\text { appendicitis }\end{array}$ \\
\hline HY & Op. ${ }^{1}$ & -31 & $\left.\begin{array}{l}9.0 \\
1.7\end{array}\right\}$ & $\left.\begin{array}{l}2 \\
8\end{array}\right\}$ & $\left.\begin{array}{r}0 \\
15\end{array}\right\}$ & 1.0 & 1 & 14 & $1^{3}$ & 2 & -1.0 & +1.2 & $\begin{array}{l}\text { Appendectomy, normal } \\
\text { appendix }\end{array}$ \\
\hline $\mathbf{P M}$ & $1^{1}$ & -49 & 6.1 & 8 & 14 & 1.94 & 1 & 17 & $5^{2}$ & 2 & & & $\begin{array}{l}\text { Appendectomy, normal } \\
\text { appendix }\end{array}$ \\
\hline VP & 11 & -23 & 3.8 & 7 & 14 & 1.0 & 3 & 18 & $4^{8}$ & 2 & -0.4 & +0.8 & $\begin{array}{l}\text { Appendectomy, acute } \\
\text { appendicitis }\end{array}$ \\
\hline JD & $1^{1}$ & -13 & 6.0 & 4 & 14 & 2.3 & 5 & 19 & $4^{3}$ & 2 & -0.4 & +1.1 & $\begin{array}{l}\text { Appendectomy, acute } \\
\text { appendicitis }\end{array}$ \\
\hline AS & Op. ${ }^{1}$ & -12 & 3.7 & 4 & 18 & 1.0 & 3 & 16 & $3^{3}$ & 2 & & & Appendectomy, normal \\
\hline RS & Op. ${ }^{1}$ & +15 & 2.5 & 2 & 12 & 2.6 & 8 & 18 & $2^{3}$ & 2 & -0.5 & +1.1 & $\begin{array}{l}\text { Appendectomy, acute } \\
\text { appendicitis }\end{array}$ \\
\hline TL & $1^{1}$ & -110 & 4.1 & 31 & 16 & 1.5 & 12 & 17 & $42^{3}$ & 43 & & & $\begin{array}{l}\text { Appendectomy, acute } \\
\text { appendicitis, compli- } \\
\text { cated by pneumonitis } \\
\text { and wound infection }\end{array}$ \\
\hline
\end{tabular}

1 Days counted from day of operation.

2 Patient on large doses of salicylates throughout course.

Temperature taken orally, $99^{\circ} \mathrm{F}$. or over.

- Patient failed to complete 24 hour specimen; otherwise this day's balance would probably have been negative. 


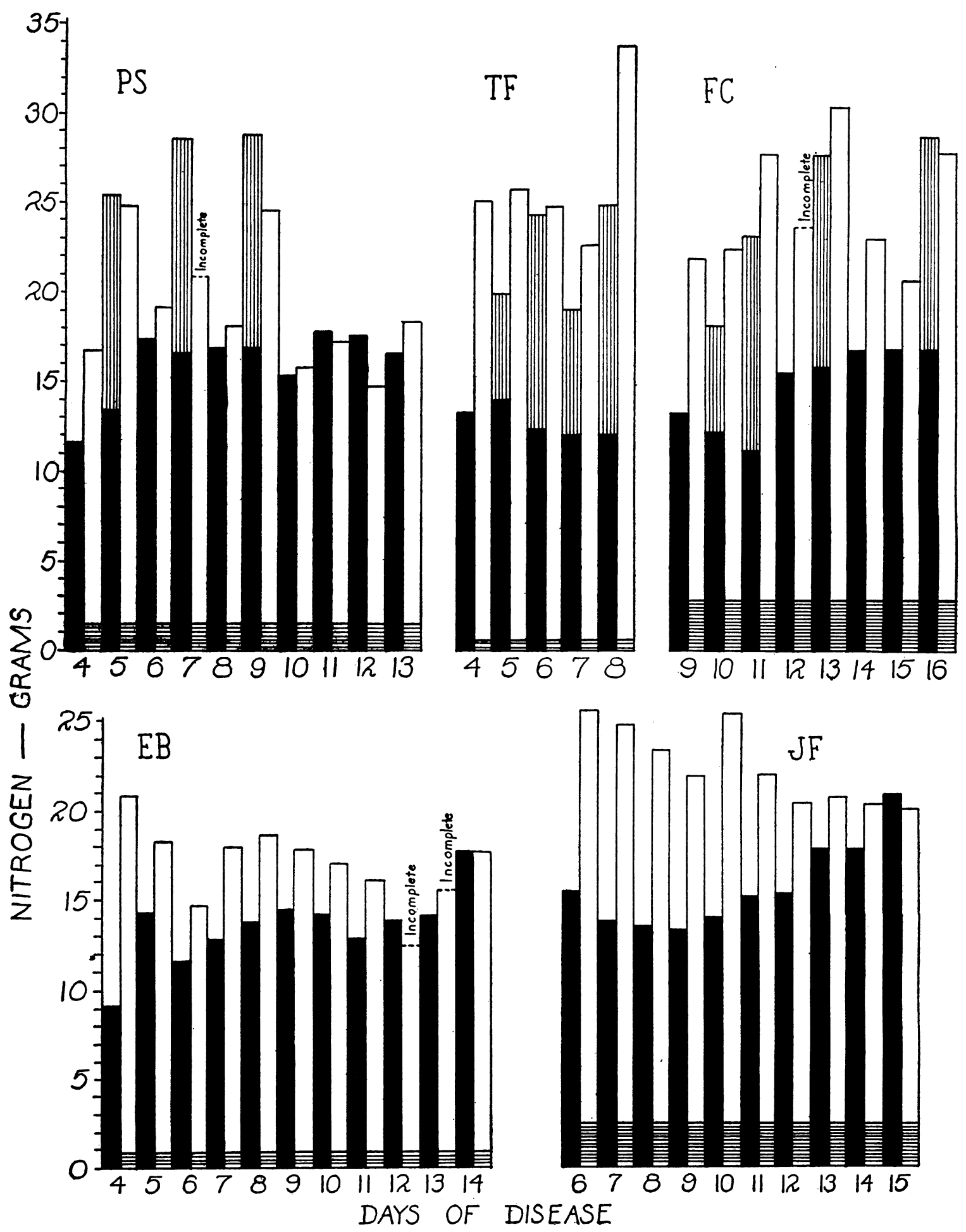

Fig. 1. The Nitrogen Metabolism of Patients with Meningococcus Meningitis

Solid columns represent nitrogen of food; vertically lined columns, nitrogen as amigen; open columns, urinary nitrogen; horizontally lined columns, fecal nitrogen. 

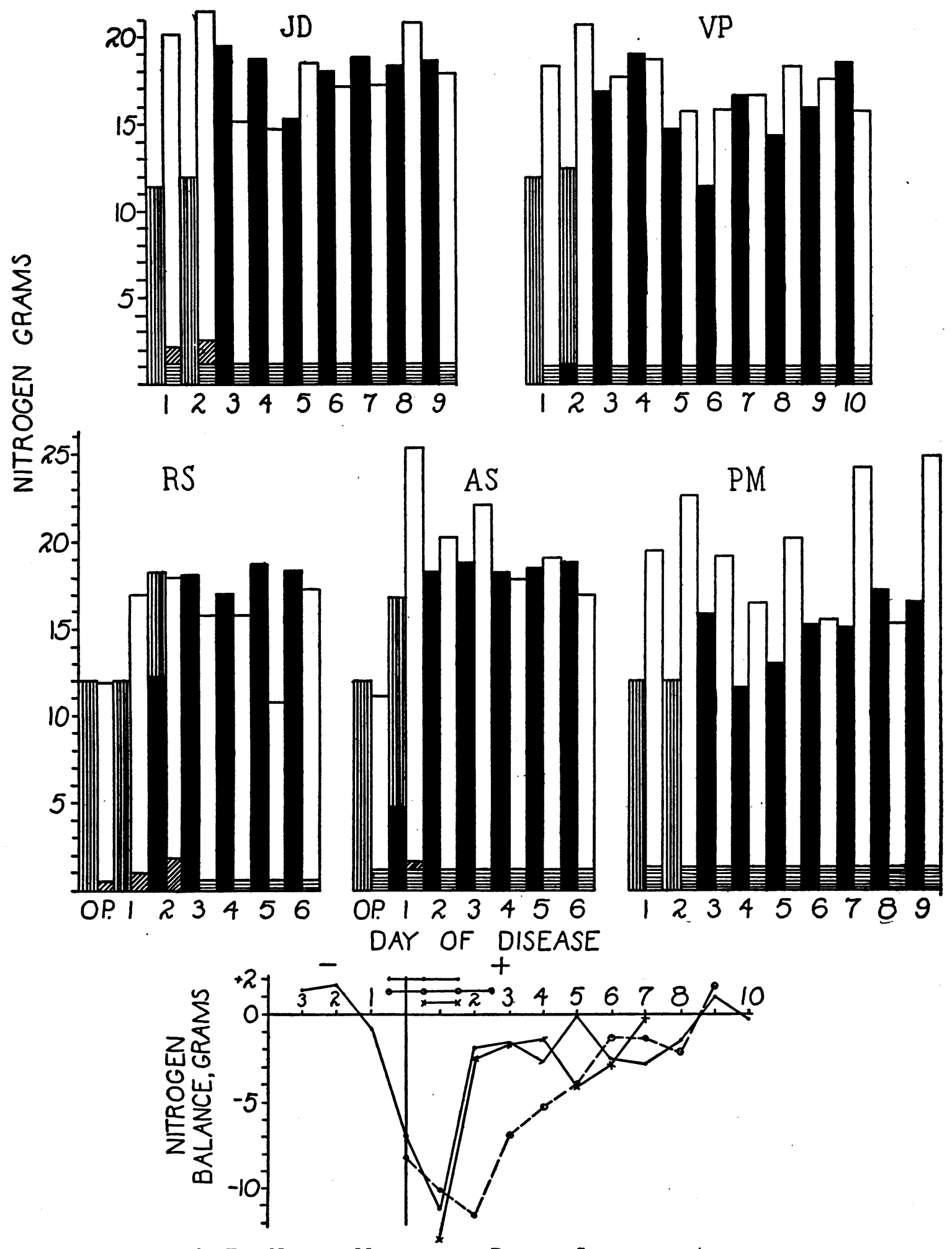

Fig. 2. The Nitrogen Metabolism of Patients Subjected to Appendectomy

Solid columns represent nitrogen of food; vertically lined columns, nitrogen as amigen; open columns, urinary nitrogen; horizontally lined columns, fecal nitrogen; diagonally lined columns, nitrogen of vomitus. OP indicates the day of operation. Day of disease in this case marks the days after operation. The graph below shows in abbreviated form the course of three additional patients who did not receive amigen injections. The vertical line represents the day of operation. The horizontal lines at the top indicate the days on which the patients received little or no food. 
these figures were those who received injections of Amigen.

\section{DISCUSSION}

A large proportion of all patients wasted nitrogen to a variable degree. This wasting bore some relation to the type and severity of the disease; but losses varied to some extent among patients with the same disease and from day to day in individual patients. In many instances, they could not be prevented by increasing nitrogen and caloric intakes within feasible limits. They frequently persisted after patients had become asymptomatic. There was no consistent relationship between these losses and the changes of serum albumin or globulin.

Losses of nitrogen in meningitis were surprisingly large and prolonged. They varied, during the periods of study from 3 grams in PSe to 180 grams in HP, who had a complicating polyarthritis with prolonged fever. This loss, equivalent to about $4.5 \mathrm{kgm}$. of muscle tissue was accompanied by a loss of $7.5 \mathrm{kgm}$. of body weight. The other patient with polyarthritis, ND, also wasted a large amount of nitrogen. PV, however, lost almost as much, 123 grams, without serious complication. Of the whole series, only PSe stored a significant quantity before discharge from the hospital. ND retained a small amount in the last 3 days before discharge; FC and JF had equivocal retentions on the last day. The remainder were still wasting when they were well enough to leave the hospital, from 8 to 25 days after the onset of illness. The losses tended to diminish as convalescence progressed; but TF and PV lost more than 12 grams each during the 2 days prior to discharge. The diets in all but one instance contained an average of 14 grams or more of nitrogen throughout the studies; during the last days of hospitalization they were usually considerably above this. One of the patients with pneumonia, $\mathrm{WZ}$, behaved in a similar manner, losing 25 grams of nitrogen from the 9th to the 17th day after the onset of his disease inclusive, although his temperature was normal after the 10th day.

More surprising are the losses in the patients with scarlet fever. These 2 subjects were afebrile and asymptomatic during the greater part of the studies; they were merely awaiting termination of their periods of isolation. From the figures for storage it is evident that replacement of the wasted nitrogen was a slow process.

In contrast to these subjects, 4 patients with long standing infections that had produced considerable wasting, TP, FS, ES, and $\mathrm{HD}$, stored nitrogen throughout their studies on diets comparable to those on which the patients with acute infections wasted nitrogen. This is similar to the phenomena which others $(2,3)$ have described in persons with fractures and other severe injuries. These subjects waste nitrogen for a considerable time after the original injury. Only after malnutrition has become advanced do they gradually reverse the process. If, during the reparative or anabolic stage, they suffer renewed injury or infection, the process of storage of nitrogen may continue uninterrupted (2).

Minor respiratory infections, not shown in the table or figures, did not disturb nitrogen metabolism appreciably.

Surgical procedures per se had no uniform effect upon nitrogen balances. There were, of course, inevitable losses on the operative and immediate postoperative days while patients received little or no nourishment. Patients who had appendectomies continued to lose nitrogen for a few days after this period in spite of more than adequate intakes and uneventful courses. This was apparently uninfluenced by the pathological state of the appendix. In spite of the fact that their appendices were normal, HY, PM, and AS lost variable amounts of nitrogen; while among the others, with different degrees of inflammation, the nitrogen balances were variable, one, $R S$, even storing nitrogen from the outset. GB after a mastoidectomy also wasted nitrogen, exclusive of the drainage which would have increased the negative balance had its nitrogen content been included. On the other hand, patients subjected to herniorrhaphy tended to store nitrogen as soon as they had passed the immediate preoperative period and were given adequate diets. JK, who had a bone cyst excised, and $\mathrm{MH}$, after ligation of the saphenous veins, lost no nitrogen. The patient LK, with the extraperitoneal hematoma, lost large amounts of nitrogen. Of the 3 patients with fractures, 2, with fractures of the femur, and of ribs, both tibiae and fibulae respectively, followed the course described by others (3), wasting nitrogen as long as they were under observation; the third, 
with a comminuted fracture of the tibia, stored small amounts of nitrogen from the beginning, although his diet was not much larger than those of the 2 subjects who wasted nitrogen.

Loss of nitrogen in the patients with acute infections was not definitely related to the febrile reaction. It is true that the largest losses in meningitis occurred in the early febrile days and continued longest in the 2 cases with polyarthritis and prolonged fever. Nitrogen continued to be wasted, however, by almost all the patients after the temperature had become normal. PV lost as much nitrogen in 5 afebrile days as he had during 6 days of fever, on several of which the temperature did not rise above $100^{\circ} \mathrm{F}$. The patients with chronic infections stored nitrogen despite elevated temperatures. The apparent correlation between temperature and negative nitrogen balances probably indicates merely that both phenomena are marks of the severity of illness.

The stools did not contain excessive amounts of nitrogen. About 2 grams of $\mathrm{N}$ per day were found in the sputum of JC with fractures of ribs and legs.

It has been suggested that the nitrogen loss in disease arises from the atrophy of disuse, induced by bed rest. If this were the case, there is no reason why herniorrhaphies should not have the same effect as appendectomies. Furthermore, nitrogen losses should not have persisted so far into convalescence in either meningitis or scarlet fever. Finally, some of the patients observed preoperatively did not waste nitrogen when confined to bed nor did some of those with acute infections, injuries, or operations.

Increasing the nitrogen intake with food or with Amigen supplements had no consistent effect. Daily intakes of over 21 grams of food nitrogen and over 25 grams of food + Amigen nitrogen failed to establish positive balances in some instances (see, for example, TF 8th day and FC 13th day in Figure 1). On other occasions (e.g., PSe in Figure 1), raising nitrogen intake sharply by means of Amigen injections seemed to mitigate or prevent losses of nitrogen. The data must be interpreted with some reserve, however, for several reasons: first, urinary nitrogen in most cases varies capriciously; second, subjects with apparently similar conditions differ in their tendency to waste nitrogen; third, the duration of the negative balance is variable; finally, there may be a delay in the excretion of nitrogen. Most of these points are illustrated in the figures. In TF, Figure 1, losses of nitrogen seem to be inversely proportional to intake, Amigen supplements apparently spare nitrogen, until the 8th day when a sudden large negative balance is associated with the largest nitrogen intake that was achieved. In most of the other cases in both figures, variability of nitrogen outputs without relation to diet is evident. After the 10th day, losses of $\mathrm{N}$ by JF, Figure 1 , seem to diminish as the dietary $\mathrm{N}$ increases. This is only a mark of general improvement, evidenced in better appetite. There is a positive balance on each of the days on which PSe, Figure 1, received Amigen supplements, with a negative balance on the alternate days. Since, however, the supplements were injected after the evening meal, a proportion of the injected nitrogen may have been excreted in the urine of the following day.

The administration of 12 grams of Amigen per day to surgical patients on the day of operation and the following day, when they received no other food, seemed to prevent losses of nitrogen for 1 day in both RS and AS. The positive balance on the operative day of AS must be discounted, however, because he had difficulty in emptying his bladder. On the whole, the losses of nitrogen in these patients who received Amigen (see detailed charts of Figure 2) were not significantly smaller than those of the patients who received no Amigen (see line charts at bottom of Figure 2).

A note of caution is in order about the use of Amigen injections as supplements to diet. Of the 14 patients who received injections, 10 developed anorexia, with or without nausea and vomiting, on 29 out of 48 occasions, although the rate of injection never exceeded 6 grams of Amigen in 2 hours and was usually slower than this. Loss of appetite, the most prominent symptom, prevented patients from eating their full meals during and immediately after infusions. It was, therefore, found advisable to give the Amigen supplements at the end of the day, some time after the evening meal, so that if the patients vomited they sacrificed little food. Since the injection of 12 grams of Amigen lasted 4 hours or more, this interfered with rest and sleep.

Except when Amigen was given, calories and 
nitrogen in the diets were roughly proportional to one another. It follows that wastage of nitrogen was no more influenced by caloric intake than by dietary protein.

It cannot be inferred from these experiments that losses of nitrogen could not have been prevented if the intake had been increased still further by injections of larger quantities of Amigen. It was not the purpose of the investigation to examine this point. It has been established that patients with acute infections, injuries, and operations of moderate severity waste nitrogen in their urine when they are given as much protein as is feasible by ordinary means. Had it not been for the special attentions of an excellent team of nurses, it would have been impossible to give the patients the high Calories and protein which they received. Results with the Amigen supplements merely serve to show that even greater efficiency in the introduction of food might have been quite as unsuccessful in preventing wasting.

Neither total serum protein nor serum albumin were significantly altered by the losses of protein sustained by these patients. Evidently, either the nature or the degree of malnutrition from which they suffered was such that it did not affect serum albumin. The amino acids of the plasma, which are not given in the table, were also unaffected.

The experiments throw no light on the causes of the obligatory destruction of protein. The conditions under which it is encountered are not those which are generally considered to be associated with great destruction of tissue. Convalescence from meningitis or scarlet fever, for example, would not fall into this category. In any case, there is no reason why the products of autolysis of tissue should not be as nutritious as products of digestion or protein hydrolysates made in the laboratory. Conversely, if the organism is unable to avail itself of autolytic products, it is not altogether surprising that it does not utilize hydrolysates or products of digestion. The old concept that there are two kinds of protein in the body, a more expendable deposit protein and the tissue proteins, might explain the difference in reactions to chronic and acute injuries and infections and possibly the preservation of serum albumin in these acute conditions. There is no obvious reason, however, why deposit protein should be less easily replaced than other protein by foods that can maintain normal nutrition and nitrogen equilibrium. It may be that some particular element of protein is expended more rapidly in the acute stages of disease. A few analyses have confirmed the observation of others that the extra urinary nitrogen is chiefly urea. This does not exclude an aberration of metabolism. Urea is the chief excretory product in the urine of animals which receive diets deficient in essential amino acids. Again it is hard to understand, however, why a similar infectious process or injury should have different effects on sound and malnourished subjects.

Because it is not possible to prevent subjects with acute infections or injuries from wasting protein by the administration of generous diets, it does not follow that efforts to feed such patients adequately should be abandoned, unless it can be shown that generous diets are positively injurious and that the nitrogen wastage is a beneficial process. After ordinary operations, negative nitrogen balances are short-lived; their occurrence and duration in acute infections are unpredictable. Besides, there is a general clinical impression that the well-being of patients is favored and convalescence accelerated by liberal diets.

This investigation has demonstrated that patients so sick that they would eat little if left to their own devices and the usual services of a hospital ward can, by assiduous nursing care, usually be induced to take 90 to 125 grams of protein and 2500 to 3500 Calories or even more daily without resort to parenteral administration of Amigen.

\section{CONCLUSION}

Patients with acute infectious diseases and following some operations were found to have negative nitrogen balances in spite of high caloric and high protein intakes. Further increases of nitrogen intake with parenteral casein hydrolysate failed to affect nitrogen equilibrium except in a few instances.

Thanks are due to Miss Alice M. Cattanach, the dietitian of the New Haven Hospital, to the nursing team, Miss Adelaide J. Kulikowski, Miss Catherine Marks, Miss Elsie McIntyre, and Mrs. Carol M. Schmitt, and to the technicians, Mrs. Jacqueline G. Mintz, Miss Dorothea Kalick, and Miss Mary F. O'Keefe. Without their services, this investigation could not have been successful. 


\section{BIBLIOGRAPHY}

1. Peters, J. P., Problems of nitrogen metabolism. Fed. Proc., 1944, 3, 197.

2. Browne, J. S. L., Schenker, V., and Stevenson, J. A. F., Some metabolic aspects of damage and convalescence. J. Clin. Invest., 1944, 23, 932.

3. Howard, J. E., Parson, W., Stein, K. E., Eisenberg, H., and Reidt, V., Studies on fracture convales- cence. I. Nitrogen metabolism after fracture and skeletal operations in healthy males. Bull. Johns Hopkins Hosp., 1944, 75, 156.

Howard, J. E., Winternitz, J., Parson, W., Bigham, R. S., Jr., and Eisenberg, H., Studies on fracture convalescence. II. The influence of diet on posttraumatic nitrogen deficit exhibited by fracture patients. Bull. Johns Hopkins Hosp., 1944, 75, 209. 